\title{
Analisis kluster Kabupaten dan Kota di Provinsi Jambi berdasarkan indikator pembangunan
}

\author{
Selamet Rahmadi \\ Prodi Ekonomi Pembangunan Fak. Ekonomi dan Bisnis, Universitas Jambi \\ E-mail korespondensi :selametselamet023@gmail.com
}

\begin{abstract}
The purpose of this study is to classify Regencies and Cities in Jambi Province based on HDI, economic growth, percentage of population growth, percentage of poor population, percentage of open unemployment rate and Gini ratio. To answer these objectives the hierarchical method used is Average Linkage (Between Groups). The of analysis were obtained, two clusters could be formed, where group 1 consisted of 10 Regencies and Cities, group 2 consisted of 1 Regencies.
\end{abstract}

Keywords: HDI, Economic growth, Percentage of population growth, Percentage of poor population

\begin{abstract}
Abstrak
Tujuan penelitian untuk mengelompokkan Kabupaten dan Kota di Provinsi Jambi berdasarkan IPM, pertumbuhan ekonomi, persentase pertumbuhan penduduk, persentase penduduk miskin, persentase tingkat pengangguran terbuka dan gini rasio. Untuk menjawab tujuan tersebut di gunakan metode hirarki yaitu Average Linkage (Between Groups). Hasil analisis dapat dibentuk dua kelompok (cluster), dimana kelompok 1 beranggotakan 10 Kabupaten dan Kota, kelompok 2 beranggotakan 1 Kabupaten.
\end{abstract}

Kata kunci: IPM, Pertumbuhan ekonomi, Persentase pertumbuhan penduduk, Persentase penduduk miskin

\section{PENDAHULUAN}

Pembangunan adalah suatu proses dalam melakukan perubahan kearah yang lebih baik. Sebagai suatu proses, maka pembangunan menghendaki adanya perubahan total dari masyarakat untuk mencapai tujuan akhir pembangunan itu sendiri yaitu mampu meningkatkan kesejahteraan masyarakat, baik secara material maupun spiritual (Todaro dan Smith, 2016).

Pembangunan daerah harus mampu mendorong terjadinya peningkatan produk domestik regional bruto (PDRB) yang diukur melalui pertumbuhan ekonomi. Pertumbuhan ekonomi menggambarkan jumlah barang dan jasa dihasilkan bertambah dan sekaligus mengindikasikan keberhasilam pembangunan ekonomi. (Nafziger,2006). Pembangunan ekonomi akan mendorong peningkatan produktivitas ekonomi masyarakat atau struktur kegiatan ekonominya. (Rostow dalam Jhingan, 2017). Peningkatan produktivitas ekonomi masyarakat akan memberi dampak terhadap meningkatnya kesejahteraan masyarakat atau pendapatan perkapita.(Sukirno, 2017).

Meningkatkan kesejahteraan masyarakat akibat adanya pembangunan melalui pertumbuhan ekonomi diharapkan memberi percepatan terhadap peningkatan output atau produksi yang dihasilkan. Peningkatan output tersebut, tentulah membutuhkan banyak faktor produksi, baik berupa modal, tenaga kerja, tanah dan teknologi melalui pembagian kerja atau spesialisasi. (David Ricardo dalam Jhingan 2017).

Penggunaan secara optimal dari faktor produksi tersebut akan mampu meningkatkan output. Karl Marx dalam Jhingan (2017), menjelaskan peningkatan output 
sebagai akibat semakin produktifnya masyarakat dalam melakukan aktivitas ekonomi dan sekaligus kunci untuk mendapatkan pendapatan yang lebih besar. Keynes dalam Jhingan (2017) lebih lanjut menjelaskan, aktivitas ekonomi meningkat, tentulah membutuhkan tenaga kerja atau mampu menggunakan tenaga kerja yang ada secara optimal (Full Emmployment). Meningkatnya kebutuhan tenaga kerja dalam aktivitas ekonomi berarti aktivitas tersebut mampu menciptakan lapangan kerja, mampu mengurangi tingkat pengangguran dan sekaligus mampu menurunkan tingkat kemiskinan serta distribusi pendapatan. (Dudley Seers dalam Arsyad, 2018)

Pembangunan ekonomi menginginkan perubahan, khususnya mampu mengurangi ketimpangan antar masyarakat, daerah dan negara. Ketimpangan pembangunan menurut Myrdal dalam Arsyad (2018) terjadi sebagai akibat pendapatan perkapita yang rendah. Ketimpangan pendapatan perkapita antar masyarakat, daerah dan negara akan mendorong kearah terciptanya distribusi pendapatan yang tidak merata. Kondisi ini akan menghambat pembangunan terutama pembangunan ekonomi.

Perubahan yang diinginkan dari pembangunan, tentulah sulit menentukan, faktor mana yang menentukan keberhasilan pembangunan tersebut. Keberhasilan pembangunan secara makro dapat dilihat dari aspek : pertumbuhan ekonomi, meningkatnya indeks pembangunan manusia, jumlah penduduk, jumlah penduduk miskin, tingkat pengangguran, gini rasio dan sebagainya. Provinsi Jambi sebagai provinsi yang terus melaksanakan pembangunan juga memperhatikan aspek-aspek tersebut. Provinsi Jambi terdiri dari 2 kota dan 9 kabupaten, jika dilihat dari aspek pertumbuhan ekonomi, indeks pembangunan manusia, jumlah penduduk, jumlah penduduk miskin, tingkat pengangguran, gini rasio setiap tahun cenderung mengalami perubahan ke arah lebih baik.

Berdasarkan BPS Provinsi Jambi, tahun 2019 Kabupaten dan Kota di Provinsi Jambi pertumbuhan ekonomi dari 11 kabupaten mengalami peningkatan di banding tahun 2018. Kota Jambi memiliki tingkat pertumbuhan ekonomi tertinggi yaitu 5,33\% dan terendah 4,25\% pada Kabupaten Tanjung Jabung Timur. IPM sebagai indikator kualitas sumberdaya manusia , maka Kota Jambi memiliki IPM tertinggi yaitu 78,26\% dan terendah Kabupaten Tanjung Jabung Timur sebesar 63,93 \%. Jumlah penduduk pada Kabupaten dan Kota juga mengalami peningkatan, peningkatan tertinggi terjadi pada Kabupaten Muaro Jambi sebesar 2,56 \% dan terendah pada Kabupaten Kerinci sebesar $0,37 \%$. Persentase penduduk miskin ditahun yang sama tertinggi terdapat di Kabupaten Tanjung Jabung Timur sebesar 11,54 \% dan terendah Kota Sungai Penuh sebesar 2,81 \%. Persentase penduduk miskin ditentukan oleh persentase tingkat pengangguran yang terjadi di setiap Kabupaten dan Kota. Tingkat pengangguran terbesar pada Kabupaten dan Kota di Provinsi Jambi pada tahun 2019 terbesar terjadi di Kota Jambi sebesar 6,72 $\%$ dan terendah di Kabupaten Tanjung Jabung Timur sebesar 1,71 \%. Sementara distribusi pendapatan yang diukur dengan indeks Gini Rasio, maka Gini Rasio terbesar terdapat di Kota Sungai Penuh sebesar 0,34 \% dan terendah terdapat di Kabupaten Bungo sebesar 0,26\%.

Banyaknya dan bervariasinya faktor yang menentukan keberhasilan pembangunan ekonomi pada Kabupaten dan Kota di Provinsi Jambi tentu menimbulkan kesulitan dalam menentukan faktor mana sesungguhnya yang menentukan keberhasilan pembangunan ekonomi. Pengidentifikasian secara tepat dari faktor-faktor tersebut dapat dilakukan dengan cara pengelompokkan daerah (clustering). Pengelompokkan daerah tersebut bertujuan untuk mengalokasikan sekelompok individu pada suatu kelompokkelompok yang saling bebas sehingga individu-individu di dalam satu kelompok yang sama mirip satu sama lain, sedangkan individu-individu di dalam kelompok yang berbeda tidak mirip.

Pengelompokkan Kabupaten dan Kota dapat dilakukan dengan menggunakan ukuran berdasarkan keserupaan atau kedekatan antar data dari faktor yang diukur untuk 
masing-masing Kabupaten dan Kota, untuk itu ukuran yang dapat digunakan adalah ukuran kedekatan atau jarak atau similaritas disebut jarak Euclidean. (Johnson dan Winchern, 2014). Melihat fenomena diatas, maka perlu dilakukan pengelompokkan Kabupaten Dan Kota di Provinsi Jambi. Pengelompokan bertujuan ingin mengetahui masing-masing Kabupaten dan Kota di Provinsi Jambi masuk kedalam kelompok mana. Pengelompokkan Kabupaten dan Kota tersebut dilakukan dengan meng gunakan indikator pertumbuhan ekonomi, indeks pembangunan manusia, jumlah penduduk, persentase penduduk miskin, tingkat pengangguran dan gini rasio.

\section{TINJAUAN PUSTAKA}

\section{Teori pertumbuhan ekonomi}

Pertumbuhan ekonomi adalah gambaran perkembangan kegiatan dalam perekonomian yang menyebabkan barang dan jasa yang diproduksikan dalam masyarakat bertambah dan merupakan tujuan utama dari pembangunan ekonomi. (Nafziger,2006). Indikator dalam mengukur pertumbuhan ekonomi suatu negara sering menggunakan Produk Domestik Bruto (PDB) dan pertumbuhan ekonomi suatu daerah Provinsi adalah PDRB (Produk Domestik Regional Bruto). (Sukirno, 2012)

Pertumbuhan ekonomi sebagai tujuan utama dari pembangunan suatu negara atau daerah dapat terjadi banyak faktor yang menentukannya. Jhingan (2017) mencoba menjelaskan beberapa teori yang menjelaskan bagaimana pertumbuhan ekonomi dapat terjadi. Teori pertumbuhan klasik menjelaskan, pertumbuhan ekonomi ditentukan oleh faktor jumlah penduduk, jumlah stok barang-barang modal, luas tanah dan kekayaan alam serta tingkat teknologi yang digunakan. Harrod-Domar dalam Arsyad (2018) menjelaskan pertumbuhan ekonomi terjadi ditentukan oleh adanya investasi. Investasi dapat meningkatkan kemampuan produkstif sekaligus menciptakan permintaan dalam perekonomian.

Teori pertumbuhan ekonomi Solow menjelaskan pertumbuhan ekonomi dapat terjadi jika ada interaksi dalam perekonomian antara pertumbuhan persediaan modal, pertumbuhan angkatan kerja dan kemajuan teknologi serta bagaimana pengaruhnya terhadap output barang dan jasa suatu negara secara keseluruhan.

\section{Teori distribuasi pendapatan (gini rasio)}

Ketimpangan pembangunan yang terjadi di suatu daerah atau wilayah membawa dampak terjadinya disparitas, baik disparitas antar wilayah, disparitas antar sektor dan disparitas antara golongan masyarakat atau individu. Disparitas yang terjadi pada golongan masyarakat atau individu menggambarkan terjadinya ketimpangan pendapatan antar golongan masyarakat atau individu. Ketimpangan pendapatan yang terjadi dapat diukur dengan menggunakan distribusi pendapatan. Distribusi pendapatan yang tidak merata terjadi, karena ditentukan oleh tingkat pembangunan, heterogenitas etnis, sifat kediktatoran dan kurangnya menghargai property rights. (Glaeser, 2006)

Distribusi pendapatan pada dasarnya dapat diukur dengan menggunakan beberapa pendekatan yaitu : Indeks Gini, Indeks Theil dan kriteria Bank Dunia. Indeks Gini adalah salah satu ukuran yang paling sering digunakan untuk mengukur tingkat ketimpangan pendapatan secara menyeluruh. Ide dasar perhitungan koefisien gini sebenarnya berasal dari upaya pengukuran luas kurva Lorenz yang menggambarkan distribusi pendapatan untuk seluruh kelompok pendapatan. Nilai koefisien gini dapat dikatagorikan atas : $<0,4$ tingkat ketimpangan rendah, 0,4 - 0,5 tingkat ketimpangan sedang dan > 0,5 tingkat ketimpangan tinggi. (Mulyadi, 2014). Robinson (2015) menjelaskan kriteria ketimpangan distribusi pendapatan menurut Bank Dunia mengukur ketimpangan distribusi pendapatan suatu negara dengan melihat besarnya kontribusi $40 \%$ penduduk termiskin. Kriterianya adalah : kelompok $40 \%$ termiskin pengeluarannya $<12 \%$ dari keseluruhan pengeluaran 
adalah ketimpangan tinggi, kelompok $40 \%$ termiskin pengeluarannya $12 \%-17 \%$ dari keseluruhan pengeluaran adalah ketimpangan sedang dan kelompok $40 \%$ termiskin pengeluarannya $>17 \%$ dari keseluruhan pengeluaran adalah ketimpangan rendah.

\section{Teori kemiskinan}

Kemiskinan menurut Badan Pusat Statistika (2018) merupakan keadaan dimana seseorang individu atau sekelompok orang tidak mampu memenuhi kebutuhan dasarnya, seperti makanan, pakaian, tempat berlindung, pendidikan, dan kesehatan yang dianggap sebagai kebutuhan minimal dan memiliki standart tertentu. BPS menetapkan ukuran standar hidup layak yaitu sebesar Rp 355,740.00/bulan, dengan kata lain, per-individu memiliki penghasilan sebesar Rp 11,000.00/hari. Penduduk yang memiliki penghasilan di bawah standar yang telah ditentukan oleh Badan Pusat Statistika dianggap sebagai penduduk miskin. (Rusdarti dan Lesta, 2013)

Kemiskinan menurut World Bank merupakan keadaan dimana seorang individu atau kelompok tidak memiliki pilihan atau peluang untuk meningkatkan taraf hirdupnya guna menjalani kehidupan yang sehat dan lebih baik sesuai standar hidup, memiliki harga diri dan dihargai oleh sesamanya. standar rasio tingkat kemiskinan yang ditetapkan oleh WorldBank sebesar \$2/day atau sekitar Rp 22,000.00/hari. (Rusdarti dan Lesta, 2013)

Robert Chamber (2008) dalam Haughton dan Shahidur (2012) mengatakan bahwa kemiskinan merupakan suatu intergrated concept yang memiliki lima dimensi sedangkan kelima dimensi tersebut membentuk suatu perangkap kemiskinan (deprivation trap), yaitu : 1). kemiskinan itu sendiri, 2). ketidakberdayaan (powerless), 3). kerentaan menghadapi situasi darurat (state of emergency), 4). ketergantungan (dependency) dan 5). keterasingan (isolation) baik secara geografis maupun sosiologis.

Stevenson (2010) menyatakan, kemiskinan diartikan tidak memiliki cukup uang untuk hal-hal dasar bahwa orang perlu untuk hidup dengan benar. Pendapat ini sesuai dengan teori kemiskinan Neo-Liberal, bahwa masalah kemiskinan merupakan persoalan individu yang disebabkan oleh kelemahan-kelemahan dan/atau pilihan-pilihan individu yang bersangkutan. Sementara teori demokrasi sosial menjelaskan, kemiskinan disebabkan oleh adanya ketidak adilan dan ketimpangan dalam masyarakat akibat tersumbatnya akses kelompok kepada sumber kemasyarakatan. Teori diatas sejalan dengan pendapat Nallari dan Griffith (2011), bahwa kemiskinan terjadi karena : memiliki jumlah yang sangat kecil dari sesuatu dan tidak baik dalam segi kualitas maupun kondisi.

Haughton dan Shahidur (2012), kemiskinan dapat terjadi karena : 1). rendahnya taraf pendidikan dan kesehatan berdampak pada keterbatasan dalam pengembangan diri dan mobilitas, 2). rendahnya derajat kesehatan dan gizi berdampak pada rendahnya daya tahan fisik, daya pikir dan selanjutnya akan mengurangi inisiatif, 3). terbatasnya lapangan pekerjaan semakin memperburuk kemiskinan, 4). kondisi terisolasi (terpencil) mengakibatkan pelayanan publik seperti pendidikan, kesehatan, dan lain-lain tidak dapat menjangkaunya dan 5). ketidak stabilan politik berdampak pada ketidak berhasilan kebijakan pro-poor.

Nurkse dalam Kuncoro (2019) menjelaskan, bahwa ketiga penyebab kemiskinan tersebut bermuara pada teori lingkaran setan kemiskinan (Vicious circle of poverty) yang menyatakan "a poor country is poor because it is poor (negara miskin itu miskin karena dia miskin) atau suatu negara menjadi miskin karena ia merupakan negara miskin ( $A$ country is poor because is poor).

\section{Teori kependudukan}

Penduduk memegang peranan besar dalam pembangunan, terutama dalam mendorong pertumbuhan ekonomi. Teori yang membicarakan tentang penduduk dalam pembangunan dikemukakan pertama kali oleh Malthus. Teori Malthus dalam Jhingan 
(2017) menyebutkan bahwa pertumbuhan penduduk mengikuti deret ukur sedangakan pertumbuhan ketersediaan pangan mengikuti deret hitung. Untuk itu pertumbuhan penduduk haruslah seimbang dengan pertumbuhan pangan atau pertumbuhan haruslah dibatasi. Jumlah penduduk yang besar dan disertai kualitas yang baik, maka menurut Karl dan Angel sebagai penganut aliran Marxist dalam Skousen (2005) akan mendorong meningkatnya aktivitas ekonomi dan semakin tinggi produksi yang dihasilkan melalui kesempatan kerja, jika teknologi tidak menggantikan tenaga manusia, jadi tidak perlu adanya pembatasan penduduk. Sementara Mill menjelaskan, semakin tinggi produktivitas seseorang maka memiliki kecenderungan ingin memiliki keluarga kecil dan sekaligus meningkatkan taraf hidupnya. Doubleday dalam Skousen (2005) berpendapat bahwa daya reproduksi penduduk berbanding terbalik dengan bahan makanan yang tersedia, jadi kenaikan kemakmuran menyebabkan turunnya daya reproduksi manusia.

\section{Teori pengangguran}

Pengangguran merupakan salah satu masalah yang besar dan vital bagi seluruh negara di dunia. Menurut Budi dan Umajah (2017) negara manapun di dunia ini baik yang dikategorikan negara maju maupun negara sedang berkembang senantiasa menghadapi masalah pengangguran, perbedaannya negara berkembang tidak mampu memberikan tunjangan kepada warga negaranya yang menganggur, sedangkan negara maju mampu memberikan jaminan itu.

Pengangguran merupakan suatu ukuran yang dilakukan jika seseorang tidak memiliki pekerjaan tetapi mereka sedang melakukan usaha secara aktif dalam empat minggu terakhir untuk mencari pekerjaan (Kaufman dan Hotchkiss, 1999). Pengangguran yang terjadi pada suatu negara ditentukan oleh banyak faktor. Hukum Okun (Okun's law), menjelaskan dimana setiap peningkatan dua persen PDB akan menurunkan satu persen jumlah pengangguran (Samuelson dan Nordhaus, 2003). Berdasarkan hukum tersebut menunjukkan, bahwa pengangguran dapat timbul bila PDB tidak mampu meningkat sebesar dua persen, maka akan mendorong peningkatan pengangguran.

Dudley Seere dalam Jhingan (2017) mejelaskan pertumbuhan yang berkesinambungan terjadi di sektor modern yang diiringi dengan terjadinya diversifikasi struktural dalam ekonomi, maka situasi ini akan menimbulkan penyerapan tenaga kerja dari sektor tradisional ke sektor-sektor yang berproduktivitas tinggi dengan upah yang juga tinggi dan pada akhirnya akan mengurangi pengangguran. Malthus dalam Jhingan (2017) menjelaskan bagaimana hubungan antara jumlah populasi, upah riil dan inflasi ialah ketika populasi tumbuh lebih cepat daripada produksi makanan maka upah riil turun maka akan mempengaruhi tingkat pengangguran. Tetapi ketika upah riil meningkat maka perusahaan akan mengurangi jumlah tenaga kerjanya, sementara penawaran lebh tinggi daripada permintaan tenaga kerja maka hal tersebut akan menyebabkan tingkat pengangguran akan meningkat.

Sejalan dengan pendapat Malthus, maka A.W Phillips menjelaskan dalam teorinya yaitu teori Kurva Phillips. Teori Kurva Phillips menjelaskan bahwa dalam jangka pendek terdapat hubungan negatif pada peningkatan tingkat upah atau inflasi pada jumlah pengangguran dan tidak dalam jangka panjang. Pendapat diatas di perkuat oleh Kaufman dan Hotckiss dalam Todaro dan Stephen (2006) yang menjelaskan bahwa penetapan tingkat upah yang dilakukan oleh pemerintah pada suatu negara akan memberikan dampak terhadap besarnya tingkat pengangguran karena semakin tinggi besaran tingkat upah yang ditetapkan akan menurunkan jumlah orang yang bekerja pada suatu negara.

\section{Indeks pembangunan manusia (IPM)}

Amartya Sen dalam Arsyad (2018) mendefinisikan pembangunan manusia sebagai perluasan kebebasan nyata yang dinikmati oleh manusia. Kebebasan bergantung pada faktor sosial ekonomi seperti akses pendidikan, kesehatan, ketenagakerjaan dan politik. 
Owen (2003) menyatakan, bahwa pembangunan suatu negara adalah pembangunan manusia bukan pembangunan benda, dimana pembangunan manusia memberi sumbangan lebih besar pada pembangunan di banding pembangunan benda (fisik).

Sumberdaya manusia yang memadai dapat memberikan kontribusi yang positif terhadap pertumbuhan ekonomi dalam mengelola segala sumber daya yang dimiliki dan mampu meningkatkan output perkapita serta daya beli masyarakat yang pada akhirnya akan meningkatkan standar hidup layak masyarakat. (Kuznet dalam Todaro dan Stephen, 2016). Meningkatnya standar hidup masyarakat memberi dampak pada peningkatan tingkat pendidikan dan harapan hidup masyarakat. (Preston dalam BPS, 2010)

Indeks Pembangunan Manusia (IPM) merupakan indikator yang dapat menjelaskan bagaimana penduduk dapat mengakses hasil pembangunan dalam memperoleh pendapatan, kesehatan, pendidikan dan sebagainya. IPM diperkenalkan oleh UNDP pada tahun 1990 dan perhitungannya menggunakan tiga (3) indikator yaitu : Indeks harapan hidup, indeks pendidikan dan indeks standar hidup layak dengan menggunakan metode rata-rata hitung. Pada tahun 2010, UNPD dalam BPS (2016) mengeluarkan cara perhitungan IPM baru yang menggunakan indikator : indeks kesehatan, indeks pendidikan dan indeks pengeluaran dengan menggunakan metode rata-rata ukur. Hasil perhitungan IPM diklasifikasikan atas empat (4) klasifikasi yaitu : IPM $\geq 80$ (sangat tinggi), $70 \leq$ IPM $<80$ (tinggi), $60 \leq$ IPM $<70$ (sedang) dan IPM $<60$ (rendah).

\section{Analisis cluster}

Analisis kelompok (cluster analysis) adalah teknik statistik yang bertujuan untuk mengelompokkan objek ke dalam suatu kelompok, dimana objek yang berada dalam satu kelompok akan memiliki kesamaan dibandingkan dengan objek yang berada di kelompok lain. (Johnson dan Winchern, 2014). Santoso (2016) menyatakan proses analisis kelompok dapat dilakukan dengan dua metode yaitu : 1). metode non hierarki, pada metode ini jumlah kelompok telah ditentukan terlebih dahulu dan 2). metode hierarki, metode hierarki digunakan bila jumlah kelompok ditentukan berdasarkan hasil analisis dan hasilnya disajikan secara bertingkat atau bertahap. Metode hierarki merupakan metode pengelompokan berdasarkan pada kemiripan sifat antar objek. Kemiripan sifat tersebut dapat ditentukan dari kedekatan jarak (jarak Euclid atau ukuran jarak Mahalanobis).

Metode Hierarki menurut Johnson dan Winchern (2014) dapat diukur dengan metode : 1). Single Linkage, membentuk kelompok dengan menggabungkan jarak paling pendek terlebih dahulu atau kemiripan yang paling besar dari individu, 2). Complete Linkage, membentuk kelompok dari individu dengan jarak paling jauh satu sama lainnya, 3). Average Linkage, membentuk kelompok dengan memperlakukan jarak antara dua cluster sebagai jarak rata-rata antara semua pasangan individu, 4). Ward's method, membentuk kelompok dengan menggunakan perhitungan yang lengkap dan memaksimumkan homogenitas di dalam satu kelompok dan 5). Centroid method, membentuk kelompok dengan menggunakan rata-rata jarak pada setiap variabel untuk semua objek. Sementara metode non hierarki, dapat diukur dengan metode k-means. (Santoso, 2016)

\section{METODE}

Penelitian ini menggunakan data sekunder yang meliputi data: IPM, pertumbuhan ekonomi (PE), persentase pertumbuhan penduduk (PPDK), persentase penduduk miskin (PDMIS), persentase tingkat pengangguran terbuka (TPENGT) dan gini rasio (GR) pada Kabupaten dan Kota di Provinsi Jambi tahun 2018. Pengelompokkan dari Kabupaten dan 
Kota dilakukan dengan menggunakan analisis cluster metode hierarki. Metode hierarki dalam mengelompokkan Kabupaten dan Kota dengan melihat jarak kedekatan atau mempunyai kesamaan paling dekat antar dua objek atau lebih. Metode yang digunakan Metode Hierarki aggomeratif yaitu metode pautan rata-rata (average linkage atau between groups). (Santoso, 2016). Hasil perhitungan metode hierarki akan mengelompokkan Kabupaten dan Kota di Provinsi Jambi dengan melihat hasil dendogram.(Wijaya, 2010) dan selanjutnya dikelompokkan menjadi 2 kelompok yaitu: kelompok dengan variabel diukur memiliki nilai diatas nilai rata-rata (tinggi)dan kelompok dengan variabel diukur memiliki nilai dibawah nilai rata-rata (rendah).

\section{HASIL DAN PEMBAHASAN}

\section{Analisis statistik deskriptif}

Analisis deskriptif digunakan untuk mengetahui nilai minimum, nilai maksimum dan nilai mean dari variabel yang diukur. Nilai rata-rata (mean) IPM Kabupaten dan Kota di Provinsi Jambi adalah 69,7364 dengan nilai terendah dan tertinggi adalah 63,32 dan 77,41 . Nilai rata-rata pertumbuhan ekonomi 5,1664 dengan nilai terendah dan tertinggi 3,47 dan 6,89. Nilai rata-rata pertumbuhan penduduk 1,4827 dengan nilai terendah dan teringgi 0,43 dan 2,64. Nilai rata-rata persentase penduduk miskin 7,8227 dengan nilai terendah dan tertinggi 2,76 dan 12,38. Nilai rata-rata tingkat pengangguran terbuka 3,6236 dengan nilai terendah dan teringgi 1,98 dan 5,55. Sementara nilai rata-rata gini rasio dengan nilai terendah dan tertinggi 0,29 dan 0,36.

Tabel 1. Statistik deskriptif tiap-tiap variabel

\begin{tabular}{llrrrr}
\hline & N & Minimum & Maximum & \multicolumn{1}{c}{ Mean } & Std. Deviation \\
\hline IPM & 11 & 63.32 & 77.41 & 69.7364 & 3.69099 \\
PE & 11 & 3.47 & 6.89 & 5.1664 & .81253 \\
PPDK & 11 & .43 & 2.64 & 1.4827 & .63991 \\
PDMIS & 11 & 2.76 & 12.38 & 7.8227 & 2.92983 \\
TPENGT & 11 & 1.98 & 5.55 & 3.6236 & 1.19466 \\
GR & 11 & .29 & .36 & .3164 & .02292 \\
Valid N (listwise) & 11 & & & & \\
\hline
\end{tabular}

Sumber : Data diolah, 2020

Kabupaten dan Kota di Provinsi Jambi memiliki nilai terendah dan tertinggi untuk tiap-tiap variabel adalah : IPM terendah Kabupaten Tanjung Jabung Timur 63,32 \% dan tertinggi Kota Jambi $77.41 \%$. Pertumbuhan ekonomi terendah Kabupaten Tanjung Jabung Timur 3,47 \% dan tertinggi Kabupaten Tanjung Jabung Barat 6,89\%. Pertumbuhan penduduk terendah Kabupaten Kerinci sebesar 0,43\% dan tertinggi Kabupaten Muaro Jambi 2,64 \%. Persentase penduduk miskin terendah Kabupaten Tanjung Jabung Timur 2,76 \% dan tertinggi Kota Sungai Penuh 12,38 \%. Tingkat pengangguran terbuka terendah Kabupaten Tebo 1,98 \% dan tertinggi Kota Jambi 5,55 $\%$. Gini Rasio terendah Kabupaten Sarolangun dan Kabupaten Tanjung Jabung Timur 0,29\% dan tertinggi Kabupaten Tanjung Jabung Barat 0,36\%. Berdasarkan Tabel 1 deskriptif , maka dapat di ketahui kabupaten dan Kota

di Provinsi Jambi yang berada di atas dan dibawah nilai rata-rata dari variabel yang diukur. 
Tabel 2. Klasifikasi Kabupaten dan Kota di Provinsi Jambi

\begin{tabular}{|c|c|c|}
\hline \multirow[t]{2}{*}{ Variabel } & \multicolumn{2}{|c|}{ Kabupaten dan Kota } \\
\hline & Dibawah rata-rata & Diatas rata-rata \\
\hline IPM & $\begin{array}{l}\text { Merangin, Sarolangun, Batanghari, } \\
\text { Muaro Jambi, Tanjung Jabung Timur, } \\
\text { Tanjung Jabung Barat, Tebo dan Bungo }\end{array}$ & $\begin{array}{l}\text { Kerinci, Kota Jambi dan Kota Sungai } \\
\text { Penuh }\end{array}$ \\
\hline $\mathrm{PE}$ & $\begin{array}{l}\text { Kerinci, Sarolangun, Tanjung Jabung } \\
\text { Timur, Tebo dan Bungo }\end{array}$ & $\begin{array}{l}\text { Merangin, Batanghari, Muaro Jambi, } \\
\text { Tanjung Jabung Barat, Kota Jambi } \\
\text { dan Kota Sungai Penuh }\end{array}$ \\
\hline PPDK & $\begin{array}{l}\text { Kerinci, Merangin, Batanghari, Tanjung } \\
\text { Jabung Timur, Kota Jambi dan Kota } \\
\text { Sungai Penuh }\end{array}$ & $\begin{array}{l}\text { Sarolangun, Muaro Jambi, Tanjung } \\
\text { Jabung Barat, Tebo dan Bungo }\end{array}$ \\
\hline PDMIS & $\begin{array}{l}\text { Kerinci, Muaro Jambi, Tebo, Bungo dan } \\
\text { Kota Sungai Penuh }\end{array}$ & $\begin{array}{l}\text { Merangin, Sarolangun, Batanghari, } \\
\text { Tanjung Jabung Barat, Tanjung } \\
\text { Jabung Timur dan Kota Jambi }\end{array}$ \\
\hline TPENGT & $\begin{array}{l}\text { Kerinci, Sarolangun, Batanghari, } \\
\text { Tanjung Jabung Timur, Tanjung Jabung } \\
\text { Barat dan Tebo }\end{array}$ & $\begin{array}{l}\text { Merangin, Muaro Jambi, Bungo, Kota } \\
\text { Jambi dan Kota Sungai Penuh }\end{array}$ \\
\hline GR & $\begin{array}{l}\text { Sarolangun, Batanghari, Muaro Jambi, } \\
\text { Tanjung Jabung Timur, Tebo dan Kota } \\
\text { Sungai Penuh }\end{array}$ & $\begin{array}{l}\text { Kerinci, Merangin, Tanjung Jabung } \\
\text { Barat, Bungo dan Kota Jambi }\end{array}$ \\
\hline
\end{tabular}

Sumber : Data diolah, 2020

\section{Mengukur jarak (Euclidean )}

Pengelompokkan Kabupaten dan Kota di Provinsi Jambi dilakukan dengan melihat hasil Tabel Promixity Matrix. Tabel ini menjelaskan jarak antara Kabupaten dan Kota. Dasar pengukurannya adalah semakin kecil nilai/jarak Euclidean, maka semakin mirip kedua kabupaten dan kota tersebut serta akan membentuk kelompok (cluster).

Tabel 3. Proximity matrix

\begin{tabular}{|c|c|c|c|c|c|c|c|c|c|c|c|}
\hline \multirow{2}{*}{ Case } & \multicolumn{11}{|c|}{ Squared Euclidean Distance } \\
\hline & 1 & 2 & 3 & 4 & 5 & 6 & 7 & 8 & 9 & 10 & 11 \\
\hline 1 & .000 & 5.521 & 8.937 & 3.457 & 16.775 & 13.719 & 15.278 & 5.402 & 8.012 & 9.106 & 6.249 \\
\hline 2 & 5.521 & .000 & 10.196 & 5.622 & 10.246 & 18.291 & 6.446 & 6.934 & 4.141 & 8.046 & 12.116 \\
\hline 3 & 8.937 & 10.196 & .000 & 4.287 & 11.827 & 10.344 & 18.044 & 1.762 & 5.405 & 17.818 & 11.577 \\
\hline 4 & 3.457 & 5.622 & 4.287 & .000 & 12.724 & 10.678 & 11.740 & 4.564 & 6.539 & 9.615 & 8.836 \\
\hline 5 & 16.775 & 10.246 & 11.827 & 12.724 & .000 & 30.758 & 20.125 & 11.294 & 2.778 & 14.387 & 9.952 \\
\hline 6 & 13.719 & 18.291 & 10.344 & 10.678 & 30.758 & .000 & 31.344 & 12.588 & 18.749 & 33.082 & 29.528 \\
\hline 7 & 15.278 & 6.446 & 18.044 & 11.740 & 20.125 & 31.344 & .000 & 13.482 & 14.973 & 18.523 & 23.722 \\
\hline 8 & 5.402 & 6.934 & 1.762 & 4.564 & 11.294 & 12.588 & 13.482 & .000 & 4.337 & 16.630 & 8.872 \\
\hline 9 & 8.012 & 4.141 & 5.405 & 6.539 & 2.778 & 18.749 & 14.973 & 4.337 & .000 & 10.015 & 7.118 \\
\hline 10 & 9.106 & 8.046 & 17.818 & 9.615 & 14.387 & 33.082 & 18.523 & 16.630 & 10.015 & .000 & 7.489 \\
\hline 11 & 6.249 & 12.116 & 11.577 & 8.836 & 9.952 & 29.528 & 23.722 & 8.872 & 7.118 & 7.489 & .000 \\
\hline
\end{tabular}

Sumber : Data diolah, 2020

Berdasarkan Tabel 3, selanjutnya dapat dilakukan proses clustering dengan menggunakan metode between group linkage yang dilakukan secara bertingkat dan hasilnya terlihat pada tabel Agglomeration Schedule. Proses aglomerasi dimulai dengan melihat jarak terdekat antar dua (2) Kabupaten dan Kota serta diikuti bergabungnya Kabupaten dan Kota ketiga (3) pada dua (2) Kabupaten dan Kota sebelumnya. Berdasarkan Tabel Agglomeration Schedule diperoleh kombinasi pengelompokkan dengan sepuluh (10) tingkatan (stage).

Pengelompokkan Kabupaten dan Kota di Provinsi Jambi dimulai dari Kabupaten dan Kota yang memiliki jarak euclidean terdekat. Kabupaten Sarolangun dan Kabupaten Tebo memiliki jarak terdekat yaitu 1,762 pada stage 1 dan ini membentuk 1 cluster. 
Selanjutnya Kabupaten dan Kota lainnya yang bergabung menjadi anggota pada cluster tersebut dengan melihat kolom next stage terlihat angka lima (5). Pada stage lima (5) menunjukkan angka satu (1), hal ini berarti Kabupaten Kerinci bergabung membentuk cluster dengan Kabupaten Sarolangun dan Kabupaten Tebo dengan rata-rata jarak terhadap dua (2) Kabupaten tersebut 7,1609. Dengan demikian pada stage 1 akan terbentuk 1 cluster yang beranggotakan tiga (3) kabupaten yaitu: Kabupaten Sarolangun, Kabupaten Tebo dan Kabupaten Kerinci.

Tabel 4. Agglomeration schedule

\begin{tabular}{|c|c|c|c|c|c|c|}
\hline \multirow{2}{*}{ Stage } & \multicolumn{2}{|c|}{ Cluster combined } & \multirow{2}{*}{ Coefficients } & \multicolumn{2}{|c|}{ Stage cluster first appears } & \multirow{2}{*}{$\begin{array}{l}\text { Next } \\
\text { stage }\end{array}$} \\
\hline & Cluster 1 & Cluster 2 & & Cluster 1 & Cluster 2 & \\
\hline 1 & 3 & 8 & 1,762 & 0 & 0 & 5 \\
\hline 2 & 5 & 9 & 2,778 & 0 & 0 & 7 \\
\hline 3 & 1 & 4 & 3,457 & 0 & 0 & 4 \\
\hline 4 & 1 & 2 & 5,572 & 3 & 0 & 5 \\
\hline 5 & 1 & 3 & 6,720 & 4 & 1 & 7 \\
\hline 6 & 10 & 11 & 7,489 & 0 & 0 & 8 \\
\hline 7 & 1 & 5 & 9,130 & 5 & 2 & 8 \\
\hline 8 & 1 & 10 & 10,738 & 7 & 6 & 9 \\
\hline 9 & 1 & 7 & 15,815 & 8 & 0 & 10 \\
\hline 10 & 1 & 6 & 20,908 & 9 & 0 & 0 \\
\hline
\end{tabular}

Sumber: Data diolah, 2020

Proses terbentuknya cluster pada tiap-tiap stage serta jumlah Kabupaten dan Kota yang menjadi anggotanya dapat dilakukan dengan cara yang sama sampai stage kesepuluh (10). Secara rinci, bagaimana proses terbentuknya cluster pada tiap-tiap stage dapat dilihat pada Tabel 5.

Tabel 5. Jumlah kabupaten dan kota setiap cluster di tiap-tiap stage

\begin{tabular}{|c|c|c|c|c|c|c|}
\hline Stage & $\begin{array}{l}\text { Jumlah } \\
\text { cluster }\end{array}$ & $\begin{array}{c}\text { Kabupaten/Kota } \\
\text { Awal }\end{array}$ & Jarak & $\begin{array}{l}\text { Kab/Kota } \\
\text { yang } \\
\text { bergabun } \\
\text { g }\end{array}$ & $\begin{array}{c}\text { Jarak } \\
\text { Ke } \\
\text { Kab/Ko } \\
\text { ta Awal }\end{array}$ & $\begin{array}{l}\text { Jumlah } \\
\text { Kabupaten/Kota } \\
\text { Setiap Cluster Di } \\
\text { Tiap-Tiap Stage }\end{array}$ \\
\hline 1 & 1 & Sarolangun dan Tebo & 1,762 & Kerinci & 7,1609 & $\begin{array}{l}\text { Sarolangun, Tebo dan } \\
\text { Kerinci }\end{array}$ \\
\hline 2 & 1 & $\begin{array}{l}\text { Muaro Jambi dan } \\
\text { Bungo }\end{array}$ & 2,778 & Kerinci & 12,3935 & $\begin{array}{l}\text { Muaro Jambi, Bungo } \\
\text { dan Kerinci }\end{array}$ \\
\hline 3 & 1 & $\begin{array}{l}\text { Kerinci dan } \\
\text { Batanghari }\end{array}$ & 3,457 & Kerinci & 1,7285 & $\begin{array}{l}\text { Kerinci, Batanghari } \\
\text { dan Kerinci }\end{array}$ \\
\hline 4 & 1 & Kerinci dan Merangin & 5,572 & Kerinci & 2,7605 & $\begin{array}{l}\text { Kerinci, Merangin dan } \\
\text { Kerinci }\end{array}$ \\
\hline 5 & 1 & $\begin{array}{l}\text { Kerinci dan } \\
\text { Sarolangun }\end{array}$ & 6,720 & Kerinci & 4,4685 & $\begin{array}{l}\text { Kerinci,Sarolangun dan } \\
\text { Kerinci }\end{array}$ \\
\hline 6 & 1 & $\begin{array}{l}\text { Kota Jambi dan } \\
\text { Sungai Penuh }\end{array}$ & 7,489 & Kerinci & 7,6775 & $\begin{array}{l}\text { Kota Jambi, Sungai } \\
\text { Penuh dan Kerinci }\end{array}$ \\
\hline 7 & 1 & $\begin{array}{l}\text { Kerinci dan Muaro } \\
\text { Jambi }\end{array}$ & 9.130 & Kerinci & 8,3875 & $\begin{array}{l}\text { Kerinci, Muaro Jambi } \\
\text { dan Kerinci }\end{array}$ \\
\hline 8 & 1 & $\begin{array}{l}\text { Kerinci dan Kota } \\
\text { Jambi }\end{array}$ & 10,738 & Kerinci & 4,553 & $\begin{array}{l}\text { Kerinci, Kota Jambi } \\
\text { dan Kerinci }\end{array}$ \\
\hline 9 & 1 & $\begin{array}{l}\text { Kerinci dan Tanjung } \\
\text { Jabung Barat }\end{array}$ & 15,815 & Kerinci & 7,639 & $\begin{array}{l}\text { Kerinci, Tanjung } \\
\text { Jabung Barat dan } \\
\text { Kerinci }\end{array}$ \\
\hline 10 & 1 & $\begin{array}{l}\text { Kerinci dan Tanjung } \\
\text { Jabung Timur }\end{array}$ & 20,908 & - & - & $\begin{array}{l}\text { Kerinci dan Tanjung } \\
\text { Jabung Timur }\end{array}$ \\
\hline
\end{tabular}

Sumber: Data diolah, 2020 
Proses aglomerasi yang dilakukan pada akhirnya akan menyatukan semua Kabupaten dan Kota di Provinsi Jambi menjadi satu (1) cluster. Jumlah cluster dengan masing-masing anggotanya yaitu Kabupaten dan Kota sangat tergantung jumlah cluster yang dibentuk (dinginkan). Hasil perhitungan tabel Cluster Membership menunjukkan jumlah cluster yang bisa dibentuk yaitu empat (4), tiga (3) dan dua (2). Jumlah cluster yang diinginkan atau dibentuk adalah dua (2) cluster.

Tabel 6. Cluster membership

\begin{tabular}{cccc}
\hline Case & 4 Clusters & 3 Clusters & 2 Clusters \\
\hline 1 & 1 & 1 & 1 \\
2 & 1 & 1 & 1 \\
3 & 1 & 1 & 1 \\
4 & 1 & 1 & 1 \\
5 & 1 & 1 & 1 \\
6 & 2 & 2 & 2 \\
7 & 3 & 3 & 1 \\
8 & 1 & 1 & 1 \\
9 & 1 & 1 & 1 \\
10 & 4 & 1 & 1 \\
11 & 4 & 1 & 1
\end{tabular}

Sumber: Data diolah, 2020

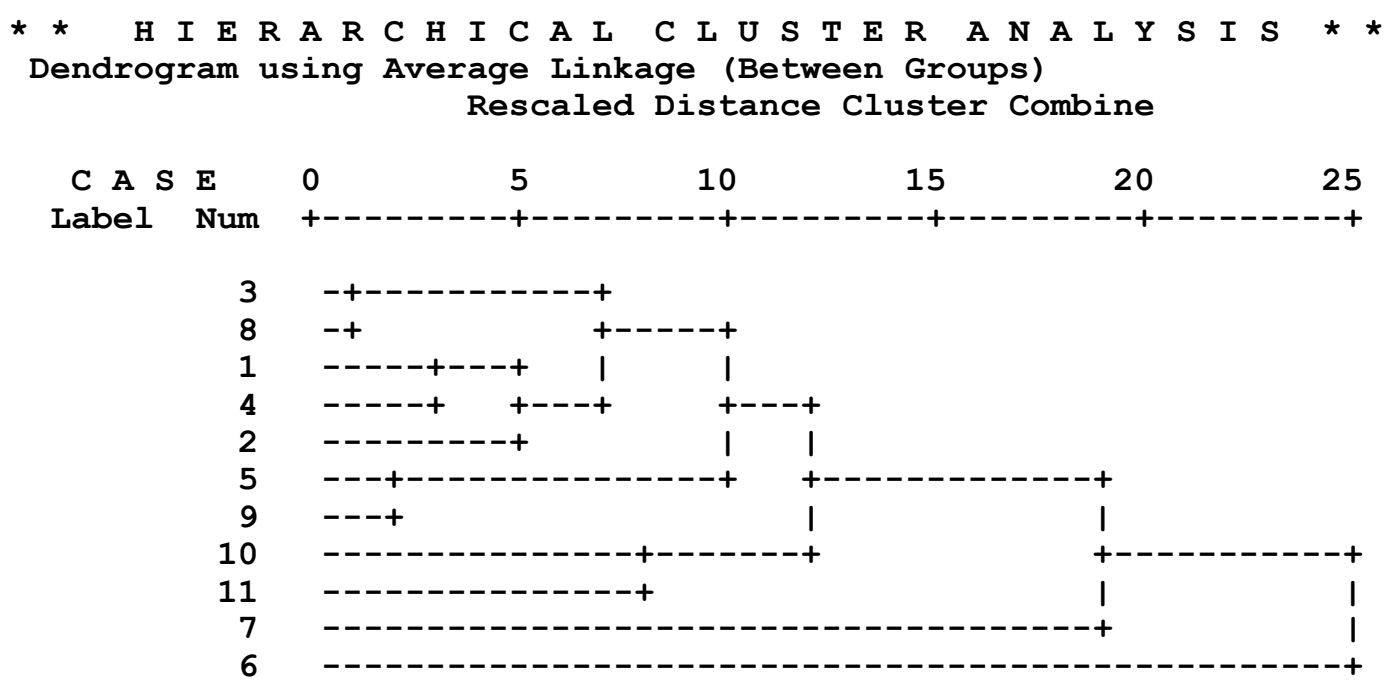

Hasil pengelompokan Kabupaten dan Kota di Provinsi Jambi berdasarkan variabel yang diukur berdasarkan tabel Cluster Membership dan Dendogram terbentuk dua kelompok (cluster) sebagai berikut :

Kelompok 1: Kabupaten Kerinci, Kabupaten Merangin, Kabupaten Sarolangun, Kabupaten Batanghari, Kabupaten Muaro Jambi, Kabupaten Tebo, Kabupaten Bungo, Kota Jambi, Kota Sungai Penuh dan Kabupaten Tanjung Jabung Barat. (memiliki nilai rata-rata tinggi)

Kelompok 2 : Kabupaten Tanjung Jabung Timur. (memiliki nilai rata-rata rendah)

\section{KESIMPULAN DAN SARAN}

\section{Kesimpulan}

Dari hasil pembahasan menggunakan metode hierarki diatas disimpulkan, pengelompokkan Kabupaten dan Kota di Provinsi Jambi yang dilihat dari variabel IPM, 
pertumbuhan ekonomi, persentase pertumbuhan penduduk, persentase penduduk miskin, persentase tingkat pengangguran terbuka dan gini rasio dapat dikelompokkan atas dua yaitu : Kelompok 1 terdiri 10 Kabupaten dan Kota yaitu : Kabupaten Kerinci, Kabupaten Merangin, Kabupaten Sarolangun, Kabupaten Batanghari, Kabupaten Muaro Jambi, Kabupaten Tebo, Kabupaten Bungo, Kota Jambi, Kota Sungai Penuh dan Kabupaten Tanjung Jabung Barat serta kelompok 2 terdiri dari 1 kabupaten yaitu : Kabupaten Tanjung Jabung Timur.

\section{Saran}

Pengelompokkan Kabupaten dan Kota yang dilakukan hanya berdasarkan data tahun 2019 dengan enam indikator keberhasilan pembangunan dan menggunakan satu metode hirarki, untuk itu dirasa perlu menambah indikator keberhasilan pembangunan lain dan metode pengelompokkan hierarki menggunakan metode lain yaitu : Single Linkage, Complete Linkage, Ward's Method, Centroid Method dan metode non hierarki untuk menyempurnakan pengelompokkan.

\section{DAFTAR PUSTAKA}

Arsyad, Lincolin. (2018). Ekonomi pembangunan, UPP STIE YKPN: Yogyakarta.

Badan Pusat Statistik (BPS), 2019, Provinsi Jambi Dalam Angka. diakses dalam http://bps.go.id, Tanggal 12 Juli 2020, Pukul 14.00 WIB

Badan Pusat Statistik (BPS). (2010). Indeks pembangunan manusia (IPM), diakses dalam http://bps.go.id, Tanggal 12 Juli 2020, Pukul 10.00 WIB

Badan Pusat Statistik, 2016, Data Indeks Pembangunan Manusia (IPM) Atau Human Development Indeks (HDI)2010-2017, diakses dalam http://bps.go.id, Tanggal 12 Juli 2020, Pukul 13.00 WIB

Badan Pusat Statistik.(2012). Indeks Pembangunan Manusia, diakses dalam http://bps.go.id, Tanggal 12 Juli 2020, Pukul 12.00 WIB

Budi, Trianggono. Hartanto Dan Umajah, Siti. Masjkuri. (2017). Analisis pengaruh jumlah penduduk, pendidikan, upah minimum dan produk domestik regional bruto (PDRB) terhadap jumlah pengangguran di kabupaten dan Kota Provinsi Jawa Timur Tahun 2010-2014, Jurnal Ilmu Ekonomi Terapan , Juni ; 2 (1), 21-30

D Chandra, S Hidayat, R Rosmeli. (2017).Dampak dana perimbangan terhadap pertumbuhan ekonomi dan ketimpangan antar daerah di Provinsi Jambi, Jurnal Paradigma Ekonomika, 12 (2), 67-76

Glaeser El. (2006). Inequality, di dalam barry $R$ weingast $B R$, wittman DA, editor. The Oxford Handbook of Political Economy, Oxford University Press Inc: New York

Haughton, Jonathan Dan Shahidur R, Khandker. (2012). Pedoman tentang kemiskinan dan ketimpangan, Salemba Empat: Jakarta.

J Junaidi, A Amir, H Hardiani. (2014). Potensi klaster agroindustri usaha mikro kecil dan menengah di Provinsi Jambi, Jurnal Perspektif Pembiayaan dan Pembangunan Daerah, 2 (1), 9-20

Jhingan, M.L. (2017). Ekonomi pembangunan dan perencanaan, Cetakan ke-15, Raja Grafindo Persada: Jakarta.

Johnson, R.A Dan D.W. Winchern. (2014). Applied multivariate statistical analysis, fifth $E d$, Prentice Hall International Inc: New Jersey.

Kaufman, Bruce E And Julie L. Hotchkiss. (1999). The economic labor markets, Georgia State University: USA

Kuncoro, Mudrajad. (2019). Ekonomika regional: Teori dan Aplikasi, Rajawali Press: Jakarta

Mulyadi, Mohammad. (2014). Kemiskinan: indentifikasi penyebab dan strategi penanggulangannya, Publica Press: Jakarta. 
Nafziger. (2006). Economic development, 4th ed, Cambridge, Univercity Press: Cambridge

Nallari, R Dan Griffith, B, (2011). Understanding growth and poverty: theory, policy and empirics, Worid Bank Publications: United states of America

Owen. R. G,. (2003). Organization behavior in Education, Englewood Clifft, Prentice Hall Inc: New Jersey.

Robinson, Tarigan. (2015). Ekonomi regional teori dan implikasi, PT. Bumi Aksara: Jakarta.

Rusdarti dan Lesta Karolina Sebayang. (2013). Faktor-faktor yang mempengaruhi tingkat kemiskinan di Provinsi Jawa Tengah, Jurnal Economia, 9(1), 1-9

Samuelson, Paul A, dan William D. Nordhaus. (2003). Ilmu makro ekonomi, Edisi Tujuh Belas, PT Media Global Edukasi: Jakarta.

Santoso, Singgih. (2016). Statistik multivariat, konsep dan aplikasi dengan SPSS, PT Elex Media Komputindo: Jakarta.

Skousen, Mark. (2005). Sang maestro teori-teori ekonomi modern, Prenada Media: Jakarta.

Stevenson, A. (2010). Oxford dictionary of english, Oxford University Press: United States of America

Sukirno, Sadono. (2012). Makroekonomi teori pengantar, Edisi Ketiga, Raja Grafindo Persada: Jakarta.

Sukirno, Sadono. (2017). Ekonomi pembangunan: proses, Masalah dan Kebijakan, Prenada Media: Jakarta.

Todaro, Michael P, dan Stephen C. Smith. (2016). Pembangunan ekonomi, Edisi sebelas, Erlangga: Jakarta.

Wijaya, Toni. (2010). Analisis multivariat teknik olah data untuk skripsi tesis dan disertasi menggunakan SPSS, Universitas Atma Jaya: Yogyakarta. 